\title{
The drivers of customer satisfaction in the hospitality industry: applying the Kano model to Sicilian hotels
}

\section{Gandolfo Dominici*}

\author{
Department S.E.A.S., \\ University of Palermo, \\ Palermo, Italy \\ Email: gandolfo.dominici@libero.it \\ *Corresponding author
}

\author{
Federica Palumbo \\ Department of Management, \\ "Sapienza" University of Rome, \\ Rome, Italy \\ Email: federica.palumbo@uniroma1.it
}

\begin{abstract}
Starting from the assessment that hotels need to embrace a managerial approach oriented towards customer satisfaction, we adopt the Kano model to identify the relevant drivers of satisfaction of hotels guest in the main cities of Sicily, Italy. This study analyses the customer satisfaction requirements for Sicilian hotels in order to suggest and weigh a set of key attributes that hotel managers need to consider in order to create an attractive offer. We base our analysis on the qualitative data collected through 600 questionnaires submitted to hotel guests of 20 Sicilian three-star hotels located in city downtowns, in different provinces and locations.
\end{abstract}

Keywords: customer satisfaction; hotel management; hospitality industry; Kano model; Sicily.

Reference to this paper should be made as follows: Dominici, G. and Palumbo, F. (2013) 'The drivers of customer satisfaction in the hospitality industry: applying the Kano model to Sicilian hotels', Int. J. Leisure and Tourism Marketing, Vol. 3, No. 3, pp.215-236.

Biographical notes: Gandolfo Dominici is a $\mathrm{PhD}$ in Business Management and tenured Assistant Professor and Chair of Marketing at the Department SEAS, University of Palermo, Italy. He is vice president and scientific director of Business Systems Laboratory; author of about 40 published articles and books, and member of the editorial board and reviewer of several international peer reviewed journals. His research activity focuses mainly on the topics of design for customer satisfaction, e-marketing and systems thinking in management.

Federica Palumbo is a $\mathrm{PhD}$ student in Business Management, Department of Management, at "Sapienza" University of Rome. She is author of several contributions on design for customer satisfaction and viable systems approach to management and reviewer for several international journals. Her research interests are customer satisfaction, systems thinking and sustainable tourism. 


\section{Introduction}

To determine the relevant drivers of customer satisfaction is particularly important for improving the offer of hotel services. For this reason, it is necessary to investigate the value drivers adopted by customers for hotel selection and for the decision to return. Research on the topic of guest satisfaction - which translates into the consideration of whether or not customers will return to a hotel or recommend it to other potential guests - is pivotal to the success of the hospitality business. On the other hand, neglecting to focus on to the hotel attributes considered most important by guests may lead to a negative overall assessment of the hotel, thus restricting the chance of repeat patronage and positive word of mouth.

This empirical research aims to identify the drivers for customer satisfaction with mid-level (three-star) hotels located in the downtown areas of the main cities of Sicily, Italy. The research question we want to answer is whether hotel service in Sicilian midlevel city hotels is satisfactory, and what are the factors that hotel management should work on in order to improve the level of guest satisfaction.

We adopt a "relationship marketing" perspective, and we apply the Kano model (1984) to propose a way to build a set of hotel services that can achieve higher levels of guest satisfaction. We measure the relevance of the requirements on hotel services from the perspective of hotel guests, in order to identify the guests' expectations and to obtain a set of relevant characteristics that can help to plan better hotel services.

We first give a theoretical framework outlining the current state-of-the-art of research in the field of customer satisfaction in the hotel industry, with particular attention paid to those studies adopting the Kano model.

In Section 3, we explain the main features of the Kano model and the reasons we chose to use this model for our analysis.

In Section 4, we apply the Kano model to a cluster of three-star city hotels in the main Sicilian cities, in order to find the drivers to be analysed by interviews with hotel guests. We discuss the results in Section 5.

We conclude by pointing out the relevance and the limitation of our findings, and the possibilities of further research.

\section{Literature overview}

One of the biggest challenges for hotel managers is to gain and sustain customer satisfaction. The increase in customer requirements for higher levels of service in the tourism industry has become increasingly obvious to researchers and professionals (Barsky and Labagh, 1992; Le Blanc, 1992; Le Blanc et al., 1996; Stevens et al., 1995, Oppermann, 1998; Lam and Zhang, 1999; Yen and Su, 2004; Dominici and Guzzo, 2010). Today, relations with guests are probably the main strategic asset of the organisation, as determining customer satisfaction is the first step in defining business objectives (Gruen et al., 2000). Positive relationships can create higher commitment among customers, positive word of mouth, and increase guests' return rate (Kim et al., 2001; Dominici and Guzzo, 2010), thus ultimately resulting in higher profitability (Oh and Parks, 1997). 
A large body of research underlines the elements which affect customers' postpurchase behaviour, such as subsequent purchases and favourable word of mouth (Berkman and Gilson, 1986; Choi and Chu, 2001; Fornell, 1992; Halstead and Page, 1992; Knutson, 1988; Pizam, 1994). There is general agreement in the literature that a satisfied guest promotes positive word of mouth with effects in term of credibility that are greater than those of conventional advertising (Tarn, 2005, Lee et al., 2006, Villanueva et al., 2008). This assessment is reinforced by the amplified effect of word of mouth on the World Wide Web (Dominici, 2009; Trusov et al. 2009).

Several studies have pointed out that guests' overall satisfaction levels result in higher probabilities of their return to the same hotel (Oppermann, 1998; Choi and Chu, 2001; Fyall et al., 2003; Sim et al., 2006). For these reasons, hotels are increasing their investment in improving services according to their perceived values for guests, so as to attain better customer satisfaction levels and to gain customers' loyalty (Jones et al., 2007). Hotel management must be aware of which service attributes are the most probable drivers of customer choice (Richard and Sundaram, 1993).

There are several studies that analyse the needs and desires of hotel guests, elucidating the relevance for guest satisfaction of a variety of attributes such as cleanliness, price, location, security, personal service, physical attractiveness, opportunities for relaxation, standard of services, appealing image, and reputation (Atkinsons, 1988; Cadotte and Turgeon, 1988; Knutson, 1988; Wilensky and Buttle, 1988; Rivers et al., 1991; Ananth et al., 1992; Barsky and Labagh, 1992; McCleary et al., 1993; Saeed et al., 2011; Mohajerani and Miremadi, 2012). Wuest et al. (1996) defined the perception of hotel attributes as the degree to which guests may find various services and facilities critical to their stay in the hotel. According to Barsky and Nash (2006), as a result of a survey carried out between 2002 and 2005 in the main hotel chains worldwide, the importance of loyalty programmes for guest's decision on where to stay increased from $32 \%$ to $34 \%$.

Another field of study investigates the relationship between service quality and customer satisfaction for hotels. Akbar et al. (2010) investigated, through a qualitative analysis conducted in Malaysia, the relationships among hotel service failures and factors such as perceived value, customer satisfaction, and loyalty in the hotel industry. They found that perceived value and customer satisfaction are the two primary variables for obtaining customer loyalty, mediating and redirecting the effect of service quality. Vijayadurai (2008) identified service quality factors in the hotel industry (service delivery, tangibles, reliability, assurance, responsiveness, empathy, service product, and social responsibility), and analysed the satisfaction of customers and their behavioural intention through the impact of service quality on guest satisfaction and behaviour.

Other pieces of research shed light on the relevance of human resource management practices to guest satisfaction (Spinelli and Canavos, 2000; Chand, 2010).

The Kano model has been applied to the topic of customer satisfaction for hotel services in other previous studies. Lee and Chen (2006) applied the Kano twodimensional quality model to Taiwan's hot spring hotels service quality evaluation; Changa and Chen (2011) integrated the Kano model with the Quality Function Deployment (QFD) to explore customers' brand contacts in the hotel business; Yang et al. (2009), used the Kano model to examine the frequency of use of service items, to propose a strategic pricing model for hotels. 


\section{The Kano model}

In this study, we apply the model proposed in 1984 by Noriaki Kano. The Kano model allows measuring and evaluating the level of customer satisfaction that emerges from the positive spread between perceived quality and expected quality. Kano provides a useful and practical approach for categorising product or service attributes according to the customers' perception and the impact on customer satisfaction.

The main differences between the Kano Model and the other models of customer satisfaction widely used in the literature - such as SERVQUAL (Parasuraman, Zeithmal and Berry, 1988) and the Critical Incident Approach (Hayes, 2008; Dominici and Guzzo, 2010) - are that the Kano Model:

- can be applied both before the consumer experience (in order to design the customer's ideal product or service) and after (to measure customer satisfaction). As Chauda et al. (2011) have indicated, the Kano Model is a useful tool for identifying customer needs and transforming these into design requirements, engineering specifications, and ultimately production details.

- does not assume the existence of a linear relationship between product/service performance and customer satisfaction. Kano noticed that customer requirements are not equivalent: some requirements, in fact, are capable of generating more satisfaction than others. Moreover, customer satisfaction is not always proportional to the functionality of the product or service, implying that higher quality does not necessarily lead to higher satisfaction.

- is useful and simple, being able to efficiently and effectively provide relevant strategic and operative information.

Kano classified product and service attributes into three primary categories, based on their impact on customer satisfaction:

- Must-be (dissatisfiers or basic factors): these requirements are considered by the customer as basic factors, and their presence thus will not increase the satisfaction level significantly. Their absence, however, will cause extreme dissatisfaction.

- One-dimensional (performance factors): these factors cause satisfaction when their performance is high, and dissatisfaction when their performance is low. These attributes are linear and symmetric (as shown in Figure 1), because they are typically connected to customer's explicit needs and desires. The company should try to be competitive here.

- Attractive (satisfiers or excitement factors): these requirements cause customer satisfaction if delivered, while they do not cause dissatisfaction if they are not delivered. Their presence strengthens the competitive advantage of the firm because such factors increase the value of the product or service as perceived by the customer. The company can use these factors to distinguish itself from its competitors in a positive way. 
In addition, Kano identified two other categories of requirements which refer to the characteristics of the product or service that customers perceive as indifferent, or even adverse, to their needs:

- Indifferent: the customer does not care about whether this feature is present or not.

- Reverse: the customer does not desire this kind of product requirement, and its presence causes a great level of dissatisfaction; its absence determines satisfaction.

Figure 1 depicts the relationship between the presence of an attribute of quality and customer satisfaction. The horizontal axis in the Kano diagram shows the state of fulfilment of a certain quality attribute, while the vertical axis displays the customer satisfaction with a certain quality attribute (Kano et al., 1984). This Kano diagram shows how each category of requirement (must-be, one-dimensional, attractive, indifferent, and reverse) has a different impact on the level of customer satisfaction. The classification of requirements proposed by the Kano model, based on their impact on customer satisfaction, allows us to identify in a specific way how the quality of the product or service might be improved.

Figure 1 Kano diagram (adapted from Kano et al., 1984)

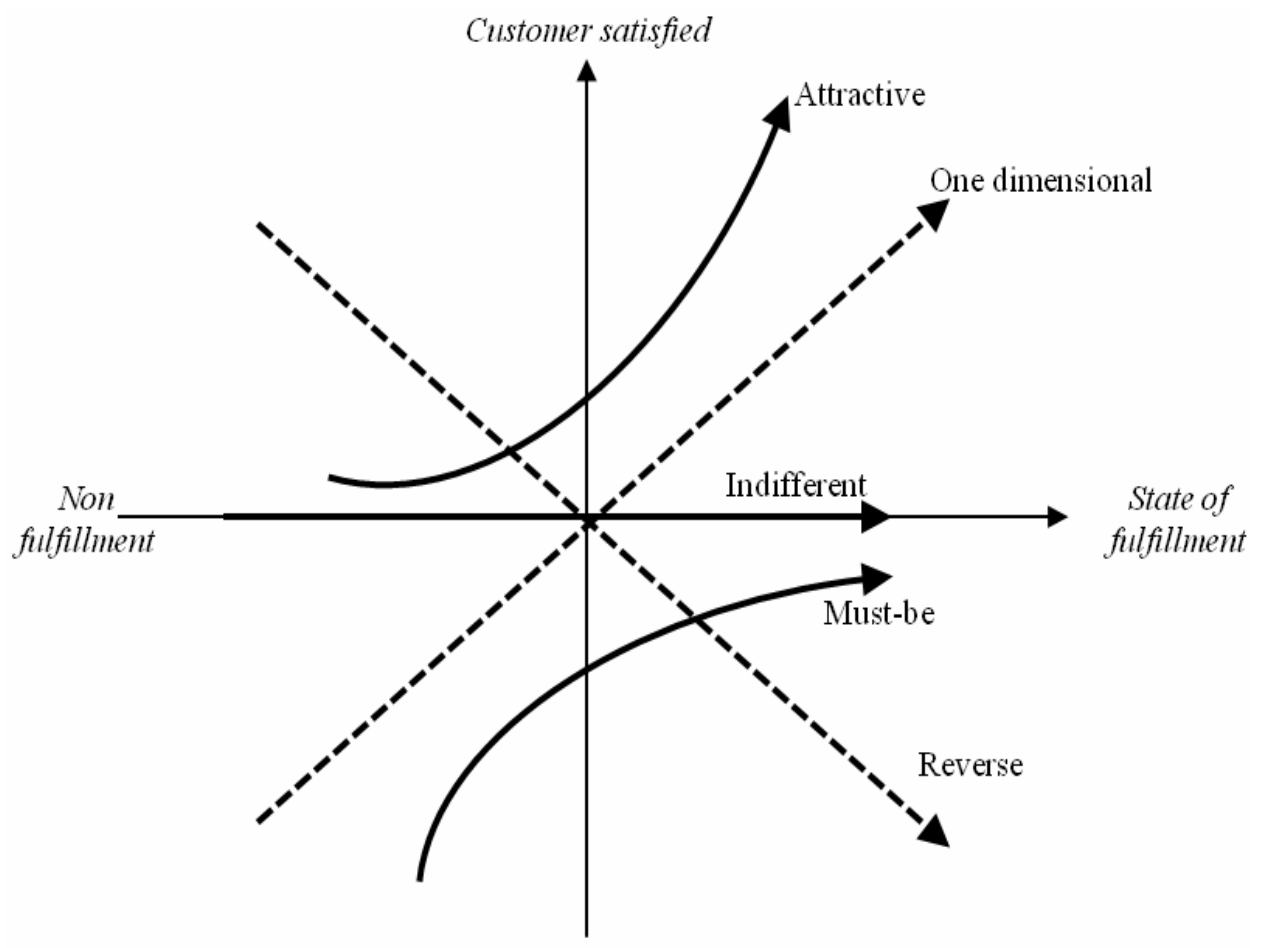

Customer dissatisfied 


\subsection{Implementing the Kano model}

The implementation of measurement in the Kano model follows four steps:

1 identification of the customer's needs;

2 development of the Kano questionnaire;

3 administration of interviews;

4 interpretation and evaluation of the results.

The identification of customer's needs (step l) can be implemented via individual interviews or through focus-group interviews with members who already know the product or service. Even if individual interviews are characterised by reduced time and cost, focus groups are usually more useful, because the interaction among the members of the group facilitates the emergence of latent needs. Typically, individual interviews are helpful in identifying one-dimensional quality attributes, while focus groups help identify attractive elements. Shiba et al. (1993) formulated five questions which are useful in this phase for investigating customers' needs:

- What associations does the customer make when using product or service $\mathrm{X}$ ?

- Which problems, defects, or complaints does the customer associate with the use of product or service $\mathrm{X}$ ?

- Which criteria does the customer take into consideration when buying product or service X?

- Which new features or services would better meet the expectations of the customer?

- What would the customer change in product or service X?

After the customers' needs and the ideal features of the product or service have been identified, it is possible to prepare the questionnaire (step 2). The Kano questionnaire is characterised by pairs of questions for each customer requirement:

- How would you feel if requirement $\mathrm{Y}$ were present in the product or service? (Functional form of the question).

- How would you feel if requirement Y were not present in the product/service? (Dysfunctional form of the question).

For each functional and dysfunctional question, the customer can select one of five alternative answers as expressions of different degrees of perception: 1. I like it that way; 2 . It must be that way; 3 . I'm neutral; 4 . I can live with it that way; 5 . I dislike it that way.

For each questionnaire, the answers to each functional-dysfunctional question pair are cross-referenced using a matrix formulated by Kano, and the perceptions are thus evaluated into quality dimensions (M: must-be requirement; I: indifferent; R: reverse; O: one-dimensional; A: attractive; Q: questionable requirements ${ }^{1}$ ). To each pair of customer perceptions, the matrix associates one requirement category. Thus, if the customer replies "I'm neutral" to the functional question and "I dislike it this way" to the dysfunctional question, the requirement, according to the Kano matrix, is a "must-be" requirement. 
In order to administrate Kano questionnaires (step 3), is necessary to identify the sample to interview and the mode of administration (online, paper, or orally).

Finally, having administered the questionnaires and collected the data, it is possible to proceed to the interpretation and evaluation stage (step 4).

Figure 2 Kano evaluation matrix (adapted from Kano et al., 1984)

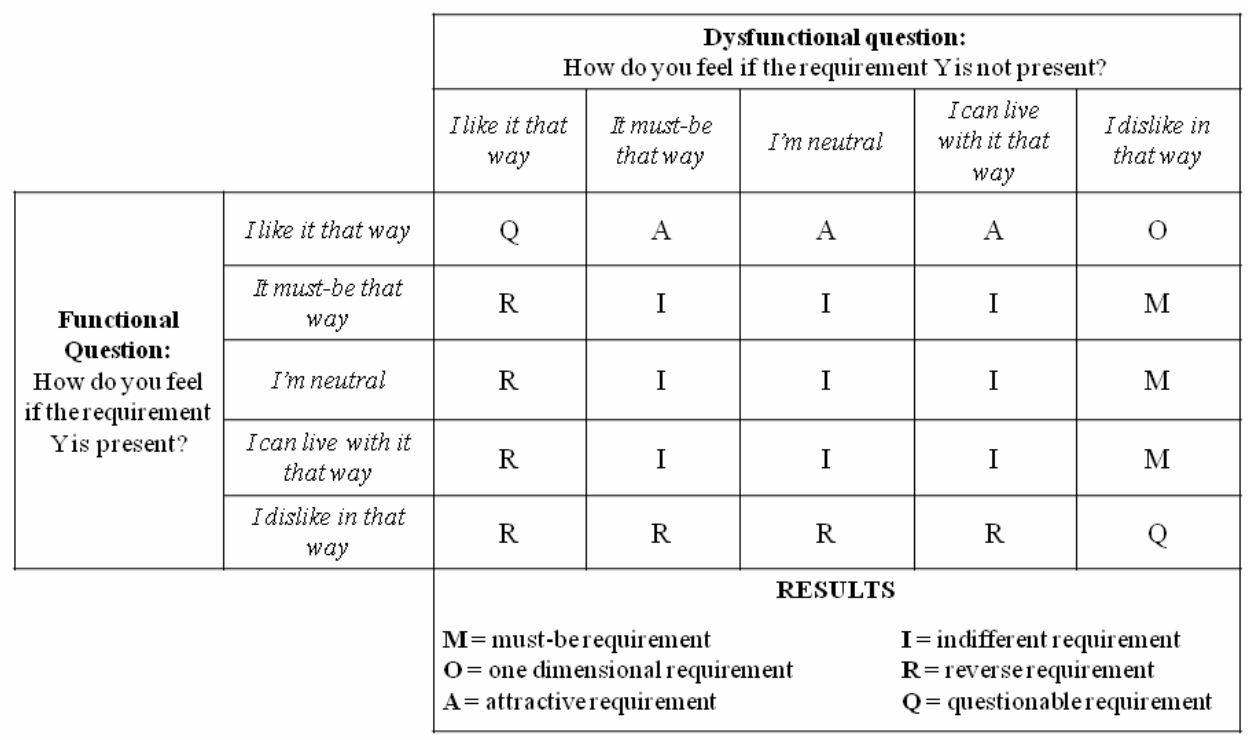

\subsection{Interpretation and evaluation}

The last phase in the development of the Kano Model is the interpretation and evaluation of the results. There are several methods for doing this (Matzler and Hinterhuner, 1998):

- Evaluation by frequency: starting from the results obtained through functionaldysfunctional matrix, each requirement can be definitively classified as belonging to one of the five categories on the basis of the highest frequency of responses.

- Evaluation by the $M>O>A>I$ rule: where it is not possible to identify a requirement as belonging to a precise category, but it is only possible to determine its generic impact on customer satisfaction, a hierarchical rule of quality-category importance can be used to design a product or service. The most important requirements that cannot be lacking in a product or service are the must-be requirements, then the onedimensional ones, then the attractive ones, and least importantly, the indifferent requirements.

- Customer satisfaction index: this method was developed by Berger in 1993. The customer satisfaction coefficient indicates whether satisfaction can be improved by meeting a product requirement, or if fulfilling this product requirement simply prevents the customer from being dissatisfied (Berger et al., 1993). To estimate the 
average impact on customer satisfaction, it is necessary to add up the attractive and one-dimensional values and to divide them by the total number of attractive, onedimensional, must-be, and indifferent responses. For the calculation of the average impact on dissatisfaction, add the must-be and one-dimensional columns and divide by the same normalising factor. The customer satisfaction index has a value between 0 and 1 , such that values close to 1 indicate great satisfaction, while values close to 0 mean low satisfaction. The customer dissatisfaction index takes values between -1 and 0 : values close to -1 indicate great dissatisfaction, while values close to 0 indicate low dissatisfaction.

Customer Satisfaction Index (CS)

$$
(\mathrm{CS})=\frac{\mathrm{A}+\mathrm{O}}{\mathrm{M}+\mathrm{O}+\mathrm{A}+\mathrm{I}}
$$

Customer Dissatisfaction Index (CS)

$$
(\mathrm{CD})=\frac{\mathrm{M}+\mathrm{O}}{\mathrm{M}+\mathrm{O}+\mathrm{A}+\mathrm{I}} \cdot(-1)
$$

Having recognised the typology of expected requirements for the product or service, the company can obtain detailed information about the best way to model its offer in order to maximise customer satisfaction. In detail, the strategic implications of the Kano Model are: fulfil all must-be requirements, be competitive regarding one-dimensional requirements, stand out with regard to attractive requirements, don't spend time or money developing a requirement that is perceived as indifferent, and avoid reverse requirements.

\section{The application of the Kano model to Sicilian hotels}

In this study we apply the Kano Model to measure the customer satisfaction of guests in Sicilian hotels, and to uncover the ideal characteristics that would better satisfy customer expectations. Our research is related to the segment of three-star hotels located in the city downtowns. We chose 20 hotels located in the major Sicilian towns, namely Palermo (7), Catania (5), Syracuse (4), Messina (2), and Trapani (2).

We applied the proposed model to our cluster, following the four steps proposed by Noriaki Kano.

\subsection{Identification of the needs and expectations of guests in Sicilian hotels}

Prior to distributing the questionnaires to the hotel guests, we held five focus-group interviews (five groups of three people) with individuals who had experience with threestar city-centre hotels. The respondents started the focus group by answering the questions formulated by Shiba et al. (1993), according to their previous satisfaction experiences.

Using their answers and the debate that followed, we have been able to identify twenty-five expected features that we have grouped into five main areas, as shown in Table 1. 
Table 1 The requirements for three-star, city-centre hotels identified by users

\begin{tabular}{|c|c|}
\hline Reception service & $\begin{array}{l}\text { - 24-hour reception } \\
\text { - Multilingual staff }\end{array}$ \\
\hline Rooms & $\begin{array}{l}\text { - Soundproof windows } \\
\text { - Air-conditioning and heating } \\
\text { - King size bed } \\
\text { - Private balcony } \\
\text { - Hydro-massage bathtub } \\
\text { - Free wireless connection } \\
\text { - Safes }\end{array}$ \\
\hline Entertainment & $\begin{array}{l}\text { - Pay TV and satellite channels } \\
\text { - Cigar Lounge } \\
\text { - Business Centre } \\
\text { - Wellness area } \\
\text { - Restaurant } \\
\text { - Night club lounge }\end{array}$ \\
\hline Transport & $\begin{array}{l}\text { - Shuttle bus from and to airport, port, station and main tourist attractions } \\
\text { - Taxi discounts } \\
\text { - Supervised car parking } \\
\text { - Car rental desk }\end{array}$ \\
\hline Additional services & $\begin{array}{l}\text { - Baby sitting } \\
\text { - Laundry service } \\
\text { - In-room breakfast service available on request } \\
\text { - Newspapers } \\
\text { - } 24 \text {-hour room service } \\
\text { - Conference Centre }\end{array}$ \\
\hline
\end{tabular}

\subsection{Development of the Kano questionnaire}

Following the identification of the requirements, we prepared the questionnaire in order to discover the nature of these requirements. Our questionnaire consisted of two parts:

- Personal information (gender, age, profession, qualifications, place of origin), duration of stay at the hotel (number of nights), reason for the visit (leisure or business), and the reason for choosing a three-star city-centre hotel.

- 50 questions in functional and dysfunctional form investigating the nature of the 25 requirements identified in step 1. The questions were grouped in classes to facilitate the overall comprehension of the survey. 


\subsection{Administration of the questionnaires and sample characteristics}

For the purpose of our study, we administered 600 questionnaires (30 for each selected hotel) to guests of Sicilian hotels. The questionnaires were administered in printed form and were available in the hotel receptions over a period of 4 months between May and July 2012. From 600, there were 504 questionnaires that were considered valid $(83 \%)$.

The total sample consists of people who were guests of the 20 selected three-star citycentre Sicilian hotels.

The sample of respondents consisted of 247 (49\%) Italian guests (59 Sicilians and 188 non-Sicilian Italians) and by 257 (51\%) people from outside of Italy.

As for sex distribution, $57 \%$ of the respondents were male, and $43 \%$ female. The average age of respondents was 52 years old. $62 \%$ of respondents have a bachelor's degree, $25 \%$ have a high-school diploma, $10 \%$ have a master's degree, and $3 \%$ have a doctorate degree, while $1 \%$ have a middle-school diploma. With regard to professions, $37 \%$ of the sample were employees, $23 \%$ were retirees, $19 \%$ were selfemployed, $11 \%$ were students, and $10 \%$ were unemployed. $38 \%$ of the respondents stayed at the hotel for only one night, $33 \%$ for 3 to 7 nights, $24 \%$ for 2 nights, and $5 \%$ for a period longer than 7 nights. 279 respondents $(55 \%)$ were on a leisure trip, while 225 $(45 \%)$ were there for business. A majority of the sample (59\%) stated that they chose a three-star hotel located in the city centre on account of the affordable price, while $39 \%$ chose it for its proximity to tourist attractions and/or work places. Only $5 \%$ of respondents had previously stayed in the same hotel. This low repeat patronage rate suggests that the hotels in the sample could improve their offer in order to increase customer loyalty.

\subsection{The interpretation and evaluation of the results}

After the data collection, we proceeded with the identification of the nature of each requirement. The output of this classification is of particular relevance to hotel managers, because it may allow them to establish a hierarchical order of requirement which can be used to redesign the offer according to the guests' desires, thus helping to achieve higher levels of customer satisfaction.

We calculated the total number of responses for each requirement, using the Kano evaluation matrix (Figure 2) to identify the categories according to the questionnaire responses.

\subsubsection{Evaluation by frequency}

We used the "evaluation by frequency" method to evaluate the results. In this way, we determined the category of each requirement on the basis of the maximum frequency obtained, as shown in Table 2. As can be seen in the table, the questionable results $(\mathrm{Q})$ have very low frequencies, implying that the questionnaire had a high level of reliability. 
Table 2 Classification of requirements in accordance with evaluation by frequency

\begin{tabular}{|c|c|c|c|c|c|c|c|}
\hline Product requirement & $O$ & $M$ & $A$ & $I$ & $R$ & $Q$ & Category \\
\hline \multicolumn{8}{|l|}{ Reception service } \\
\hline 1. 24-hour reception & $\underline{212}$ & 143 & 45 & 91 & 13 & 0 & One dimensional \\
\hline 2. Multilingual staff & 172 & $\underline{215}$ & 17 & 97 & 2 & 1 & Must-be \\
\hline \multicolumn{8}{|l|}{ Rooms } \\
\hline 3. Soundproof windows & 113 & 63 & $\underline{186}$ & 115 & 24 & 3 & Attractive \\
\hline 4. Air-conditioning and heating & 186 & $\underline{243}$ & 34 & 13 & 27 & 1 & Must-be \\
\hline 5. King size bed & 97 & 34 & $\underline{223}$ & 134 & 14 & 2 & Attractive \\
\hline 6. Private balcony & 138 & 49 & 83 & $\underline{193}$ & 41 & 0 & Indifferent \\
\hline 7. Hydro-massage bathtub & 45 & 2 & $\underline{276}$ & 103 & 76 & 2 & Attractive \\
\hline 8. Free wireless connection & $\underline{163}$ & 95 & 124 & 89 & 33 & 0 & One dimensional \\
\hline 9. Safes & $\underline{245}$ & 88 & 21 & 134 & 13 & 3 & One dimensional \\
\hline \multicolumn{8}{|l|}{ Entertainment } \\
\hline 10. Pay TV and satellite channels & $\underline{148}$ & 69 & 144 & 96 & 45 & 2 & One dimensional \\
\hline 11. Cigar Lounge & 89 & 21 & $\underline{169}$ & 133 & 89 & 3 & Attractive \\
\hline 12. Business Centre & $\underline{183}$ & 63 & 107 & 139 & 12 & 0 & One dimensional \\
\hline 13. Wellness area & 166 & 21 & $\underline{264}$ & 45 & 7 & 1 & Attractive \\
\hline 14. Restaurant & $\underline{183}$ & 107 & 129 & 63 & 21 & 1 & One dimensional \\
\hline 15. Night club lounge & 43 & 19 & 135 & 78 & $\underline{226}$ & 3 & Reverse \\
\hline \multicolumn{8}{|l|}{ Transport } \\
\hline $\begin{array}{l}\text { 16. Shuttle bus from and to } \\
\text { airport, port, station and } \\
\text { main tourist attractions }\end{array}$ & $\underline{187}$ & 132 & 101 & 56 & 26 & 2 & One dimensional \\
\hline 17. Taxi discounts & 174 & 43 & $\underline{204}$ & 67 & 16 & 0 & Attractive \\
\hline 18. Supervised car parking & 102 & 23 & 121 & $\underline{215}$ & 42 & 1 & Indifferent \\
\hline 19. Car rental desk & 27 & 15 & 86 & $\underline{247}$ & 127 & 2 & Indifferent \\
\hline \multicolumn{8}{|l|}{ Additional services } \\
\hline 20. Baby sitting & 96 & 48 & 123 & $\underline{189}$ & 48 & 0 & Indifferent \\
\hline 21. Laundry service & 135 & 36 & 98 & $\underline{195}$ & 39 & 1 & Indifferent \\
\hline 22. In-room breakfast service & 98 & 23 & $\underline{245}$ & 121 & 15 & 2 & Attractive \\
\hline 23. Newspapers & 129 & 61 & $\underline{217}$ & 78 & 18 & 1 & Attractive \\
\hline 24. 24-hour room service & 42 & 25 & 117 & $\underline{284}$ & 34 & 2 & Indifferent \\
\hline 25. Conference Centre & 79 & 35 & 62 & $\underline{244}$ & 84 & 0 & Indifferent \\
\hline
\end{tabular}

The results obtained were:

- 2 must-be requirements: multilingual staff; air-conditioning and heating.

- 7 one-dimensional requirements: 24-hour reception; free wireless connection; safes; pay TV and satellite channels; business centre; restaurant; shuttle bus from and to airport, port, station, and main tourist attractions. 
- 8 attractive requirements: soundproof windows; king-size bed; hydromassage bathtub; cigar lounge; wellness area; taxi discounts; in-room breakfast service available on request; newspapers.

- 7 indifferent requirements: private balcony; supervised car parking; car-rental desk; babysitting; laundry service; 24-hour room service; conference centre.

- 1 reverse requirement: nightclub lounge.

There are only two requirements that are necessary to satisfy the basic needs of hotel guests (must-be requirements): multilingual staff and air-conditioning and heating. Their presence does not increase customer satisfaction, while their absence causes great dissatisfaction, because consumers take these items for granted. In particular, the need for multilingual staff arises because a three-star hotel located in the city centre usually has a high proportion of foreign guests. Concerning air-conditioning and heating, the former is particularly important for the wellbeing of guests, given how hot Sicilian summers are. In other words, even when considering cheap three-star hotels, air-conditioning and heating and multilingual staff must always be present. Although their presence does not increase the level of customer satisfaction, their absence would strongly decrease it.

We found seven one-dimensional requirements, whose presence in the service offer is proportionally related to customer satisfaction. One of these is a 24-hour reception: hotel guests are reassured when there is always someone at the reception ready to meet their demands. Two other one-dimensional requirements are related to room features: free wireless connections to allow guests to access the internet with their own laptops, smart phones, and tablets, and the presence of a safe in the room, in which customers can store valuables and money. In addition, three other one-dimensional requirements were observed: pay TV and satellite channels, a business centre, and a restaurant. We put these requirements under the "entertainment" macro class, because they are related to hotel guests' free time. The requirement of "Pay TV and satellite channels" in every room, allow hotel guests to feel at home and watch their favourite TV programmes. This requirement is also considered very useful by foreign tourists, because satellite channels are international. The "business centre" refers to an area, usually located in the common spaces of the hotel, in which guests can find computers, fax machines, printers, an Internet connection, and a photocopying service. This requirement gives guests who have not brought their own computers the opportunity, to work, access email, print tickets, search for information about places to visit, communicate with others, and so on. Even though this is not a "must-be" requirement, it is strongly recommended in today's digital world. A restaurant is also considered important by hotel guests, in particular by business travellers who usually do not have time or the company to have dinner outside the hotel: its presence increases customer satisfaction, while its absence decreases customer satisfaction. The final one-dimensional requirement is that of a shuttle bus service from and to the airport, port, station, and main tourist attractions. Even though the hotels in our cluster are located in the city downtowns, tourists are often disappointed by the quality of transport connections in Sicily. In order to avoid these complaints, hotels could offer such a service, possibly using synergies and agreements with other hotels in the same area.

We found eight attractive requirements. Hotels are free to decide whether to include these requirements in their offer, as their presence causes high satisfaction though their absence does not cause dissatisfaction. However, the presence of this kind of requirement is useful to differentiate a hotel's offer from that of competitors and to increase the perceived value of the hotel. 
The first attractive requirement is the presence of soundproof windows in the rooms: this is recommended in particular in those hotel rooms that are located near noisy streets and on lower floors. Another attractive requirement is a king-size bed: guests may be very happy to find a larger and more comfortable bed. One additional attractive requirement related to room features is the presence of whirlpool baths in the bathrooms.

Other two attractive requirements are cigar lounges and wellness areas. A cigar lounge is conceived of as a place for smokers where guests can chat with others, sipping a drink and reading a book in a pleasant atmosphere. Wellness areas are increasingly expected by clients, and can include gyms, swimming pools, saunas, massage centres, beauty salons, and so on.

The two final attractive requirements are in-room breakfasts on request and free newspapers in the morning. These requirements are very cheap to implement, but they nonetheless increase the perceived value of and improve the image of the hotel.

Hotels should not invest in fulfilling indifferent requirements, because such actions do not increase or decrease customer satisfaction. In this research we found seven indifferent requirements.

The first of these indifferent requirements is the presence of a private balcony with a panoramic view in each room. Such a requirement does not fit with customers' expectations, as guests who choose a three-star city-centre hotel are mainly interested in a convenient and comfortable service at low cost; they tend not to care very much about panoramic views. In any case, the high levels of smog and pollution do not make it enjoyable to sit outside. For hotels, the only problematic part of rooms without private balconies is that guests might smoke inside the rooms. For this reason, it may be a good idea to create a place for smokers in the hotel, such as the cigar lounge.

Other two indifferent requirements are supervised car parking and the presence of a car-rental desk in the main hall. According to respondents, such requirements are not important, because people who decide to stay in a downtown hotel do not usually take a car with them; they are also typically uninterested in having one, considering the bad traffic jams in Sicilian cities.

The other four additional services that guests considered indifferent in our research were:

- babysitting services: people who stay in this type of hotel usually are not usually travelling with children. If they are, they typically do not leave the children alone during the day;

- laundry service: people usually stay in such hotels for only a few nights - not long enough to need a laundry service;

- 24/7 room service: guests who choose a three-star hotel usually do not want to pay for this kind of service;

- conference centre: most guests do not travel for conferences and, according to the answers to our questionnaires, even those who travel to attend a conference do not care to get accommodation in the same hotel where the conference is held.

We found only one requirement that was considered reverse by respondents: the presence of a nightclub lounge in the hotel. Hotel guests are absolutely adverse to the presence of such a lounge, because they believe that a nightclub would create noise and disturb sleep. 


\subsection{2 $M>O>A>$ I rule}

The $\mathrm{M}>\mathrm{O}>\mathrm{A}>\mathrm{I}$ rule can be conceived as a useful guideline for efficiently directing investments in order to design or redesign the offer of a tourist hotel.

By analysing the results of the evaluation by frequency and applying the hierarchical rule of $\mathrm{M}>\mathrm{O}>\mathrm{A}>\mathrm{I}$, some practical indications emerge. If managers wish to redesign a hotel's offer according to customers' needs, they will first of all ensure the presence of the must-be requirements: multilingual staff and air-conditioning and heating.

Having fulfilled these fundamental requirements, they should then invest their remaining resources to fulfil the one-dimensional requirements previously indicated: 24-hour reception, a free wireless connection, safes, pay TV and satellite channels, a business centre, a restaurant, and shuttle buses from and to the airport, port, station, and main tourist attractions. The presence of these requirements, together with the must-be features, is essential to ensure the minimum level of customer satisfaction.

If there are additional available resources, the hotel's offer could be enriched by several of the requirements identified as attractive: soundproof windows; king-size beds; hydromassage bathtubs; a cigar lounge; a wellness area; taxi discounts; an in-room breakfast service on request; and free newspapers.

Hotel managers should completely avoid investing resources in the indifferent requirements - namely private balconies, supervised car parking, car-rental desks, babysitting services, laundry services, 24-hour room service, conference centres - and most especially in the reverse requirement: nightclub lounges.

\subsubsection{Customer satisfaction and dissatisfaction indices}

To summarise and verify the findings of the application of the Kano Model, we calculated the customer satisfaction index and the customer dissatisfaction index for each requirement, in order to confirm whether or not they coincide with the results obtained through the Kano Model.

The results of the customer satisfaction index indicate that:

- Attractive requirements have the greatest impact on customer satisfaction, as their value is closer to 1 : wellness area $(+0.87)$, taxi discounts $(+0.77)$, hydromassage bathtub $(+0.75)$, newspapers $(+0.71)$, in-room breakfast service $(+0.70)$, and so on. These results are in line with the results of the Kano Model. According to that model, in fact, the presence of attractive requirements increases the level of customer satisfaction more than do the other requirements.

- Must-be and indifferent requirements have low levels of customer satisfaction index. These results also agree with the Kano Model: in fact, the presence of indifferent and must-be requirements do not determine satisfaction.

With regard to the customer dissatisfaction index, we can observe that:

- The requirements whose absence cause the greatest level of dissatisfaction are those rated as must-be (air-conditioning and heating $(-0.90)$ and multilingual staff $(-0.77)$ ) or one-dimensional (24-hour reception (-0.70)). Must-be requirements cause a high degree of dissatisfaction when they are not provided, because customers take their 
presence for granted. One-dimensional requirements are proportionally correlated with customer satisfaction, hence their absence causes dissatisfaction. These results confirm the Kano Model findings.

- The requirements that cause low degrees of dissatisfaction when not provided are hydromassage bathtubs $(-0.11)$ and car-rental desks $(-0.11)$. They are attractive and indifferent requirements, so their absence does not cause excessive dissatisfaction, according to the Kano model.

Table 3 Customer satisfaction and dissatisfaction indices for each hotel offer requirement

\begin{tabular}{|c|c|c|}
\hline & $C S$ & $C D$ \\
\hline 1. 24-hour reception service & +0.52 & -0.72 \\
\hline 2. Multilingual staff & +0.38 & -0.77 \\
\hline 3. Soundproof windows & +0.63 & -0.37 \\
\hline 4. Air-conditioning and heating & +0.46 & -0.90 \\
\hline 5. King size bed & +0.66 & -0.27 \\
\hline 6. Private balcony & +0.48 & -0.40 \\
\hline 7. Hydro-massage bathtub & +0.75 & -0.11 \\
\hline 8. Free wireless connection & +0.61 & -0.55 \\
\hline 9. Safes & +0.55 & -0.68 \\
\hline 10. Pay TV and satellite channels & +0.64 & -0.47 \\
\hline 11. Cigar Lounge & +0.63 & -0.27 \\
\hline 12. Business Centre & +0.59 & -0.5 \\
\hline 13. Wellness area & +0.87 & -0.38 \\
\hline 14. Restaurant & +0.65 & -0.60 \\
\hline 15. Night club lounge & +0.65 & -0.23 \\
\hline 16. Shuttle bus & +0.61 & -0.67 \\
\hline 17. Taxi discounts & +0.77 & -0.44 \\
\hline 18. Supervised car parking & +0.48 & -0.27 \\
\hline 19. Car rental desk & +0.30 & -0.11 \\
\hline 20. Baby sitting & +0.48 & -0.32 \\
\hline 21. Laundry service & +0.50 & -0.37 \\
\hline 22. In-room breakfast service & +0.70 & -0.25 \\
\hline 23. Newspapers & +0.71 & -0.39 \\
\hline 24. 24-hour room service & +0.34 & -0.14 \\
\hline Conference Centre & +0.33 & -0.27 \\
\hline
\end{tabular}

Figure 3 synthesises the results of the customer satisfaction and customer dissatisfaction indices for each requirement. In the comments and in Figure 3 we excluded the nightclub requirement, as it was not included in the calculation of the CS and CD indices. 
Figure 3 Influence of hotel offer requirements on satisfaction and dissatisfaction

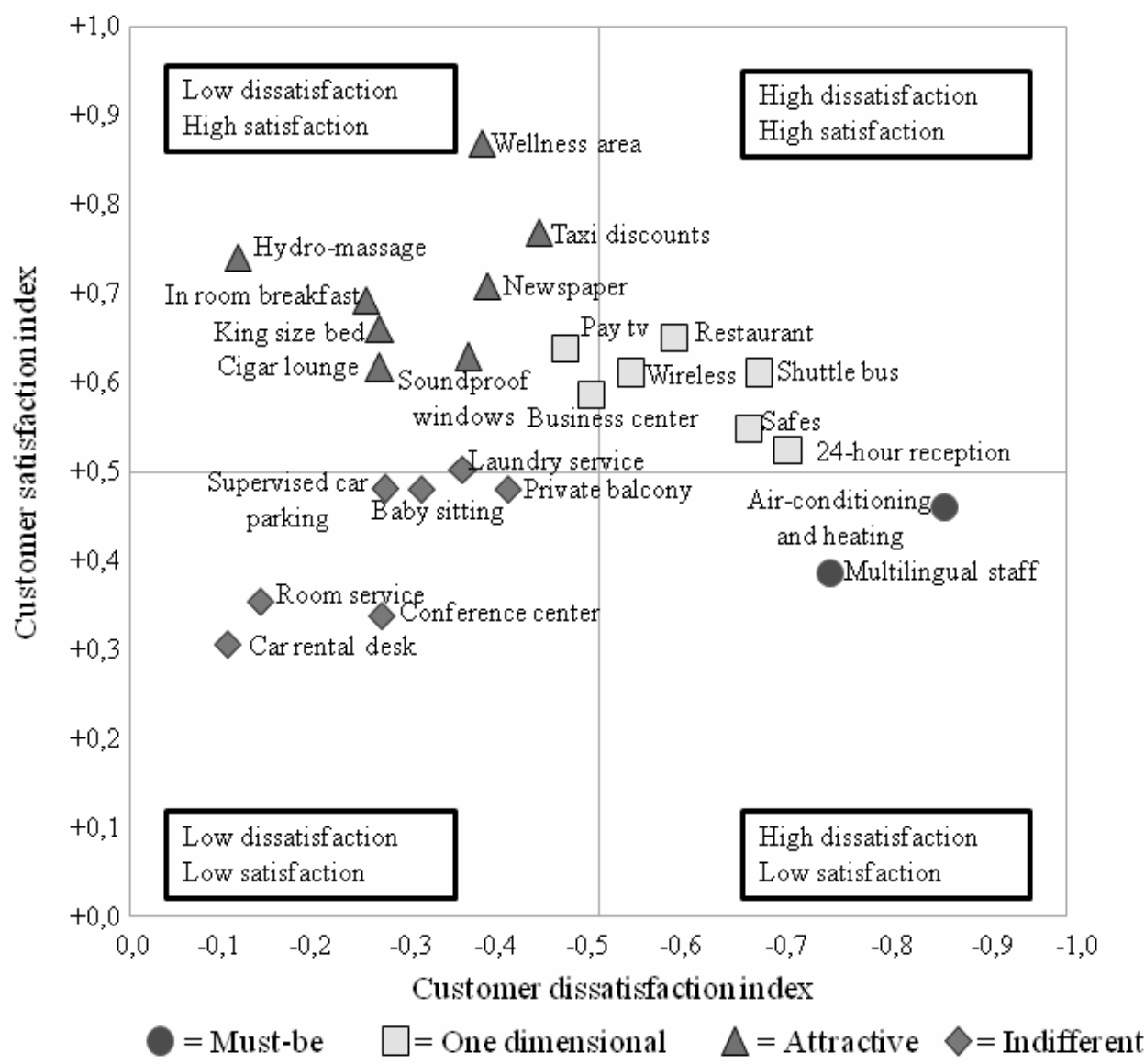

The obtained customer satisfaction and dissatisfaction indices confirm the results of the Kano model (see Figure 3). These indices also supply a numerical guideline for hotel managers who, by examining the values of these indices, can better understand how to increase customer satisfaction and decrease customer dissatisfaction.

\section{The fulfilment of requirements in our cluster of Sicilian hotels}

In the final phase of our study, we checked the presence of the 25 requirements identified by the Kano model in the 20 Sicilian hotels of our sample (see Table 4).

There are requirements which are present in many hotels, such as 24-hour receptions, air-conditioning and heating, multilingual staff, free wireless connections, and the presence of room safes. These requirements are must-be and one-dimensional, and so their presence has a positive impact on customer satisfaction. 
The drivers of customer satisfaction in the hospitality industry

Table 4 Fulfilment of requirements in the examined hotels

\begin{tabular}{|c|c|c|}
\hline Requirement & $\begin{array}{l}\text { Number of hotel in the sample } \\
\text { which fulfilled the requirement }\end{array}$ & $\begin{array}{c}\text { Percentage of fulfilment } \\
\text { in the sample }\end{array}$ \\
\hline 1. 24-hour reception service & 17 & $85 \%$ \\
\hline 2. Multilingual staff & 16 & $80 \%$ \\
\hline 3. Soundproof windows & 9 & $45 \%$ \\
\hline 4. Air-conditioning and heating & 19 & $95 \%$ \\
\hline 5. King size bed & 2 & $10 \%$ \\
\hline 6. Private balcony & 7 & $35 \%$ \\
\hline 7. Hydro-massage bathtub & - & - \\
\hline 8. Free wireless connection & 18 & $90 \%$ \\
\hline 9. Safes & 17 & $85 \%$ \\
\hline 10. Pay TV and satellite channels & 4 & $20 \%$ \\
\hline 11. Cigar Lounge & 9 & $45 \%$ \\
\hline 12. Business Centre & 14 & $70 \%$ \\
\hline 13. Wellness area & 3 & $15 \%$ \\
\hline 14. Restaurant & 6 & $30 \%$ \\
\hline 15. Night club lounge & 1 & $5 \%$ \\
\hline 16. Shuttle bus & 9 & $45 \%$ \\
\hline 17. Taxi discounts & - & - \\
\hline 18. Supervised car parking & 13 & $65 \%$ \\
\hline 19. Car rental desk & 6 & $30 \%$ \\
\hline 20. Baby sitting & 2 & $10 \%$ \\
\hline 21. Laundry service & 8 & $40 \%$ \\
\hline 22. In-room breakfast service & 14 & $70 \%$ \\
\hline 23. Newspapers & 8 & $40 \%$ \\
\hline 24. 24-hour room service & 13 & $65 \%$ \\
\hline 25. Conference Centre & 7 & $35 \%$ \\
\hline
\end{tabular}

There are also requirements, such as hydromassage bathtubs and taxi discounts, which are not present in all the hotels, even though they are considered attractive by clients. The fulfilment of these requirements is suggested as a way of improving customer satisfaction.

The reverse requirement - the nightclub lounge - is present in only one hotel of the sample.

In order to evaluate the general level of customer satisfaction and to identify possible improvements in the offer of Sicilian hotels, we have applied the Kano diagram (see Figure 4) to the results of our analysis. The Kano diagram compares the state of fulfilment of requirements with their impact on customer satisfaction. We calculated the fulfilment index using the aggregate data from the sample (see Table 4 "percentage of 
fulfilment in the sample"), while we used the customer satisfaction index as a proxy for customer satisfaction. In Figure 4, we omitted the nightclub lounge requirement, because it was not included in the calculation of the CS index.

Figure 4 Kano diagram of requirements in Sicilian hotel offers

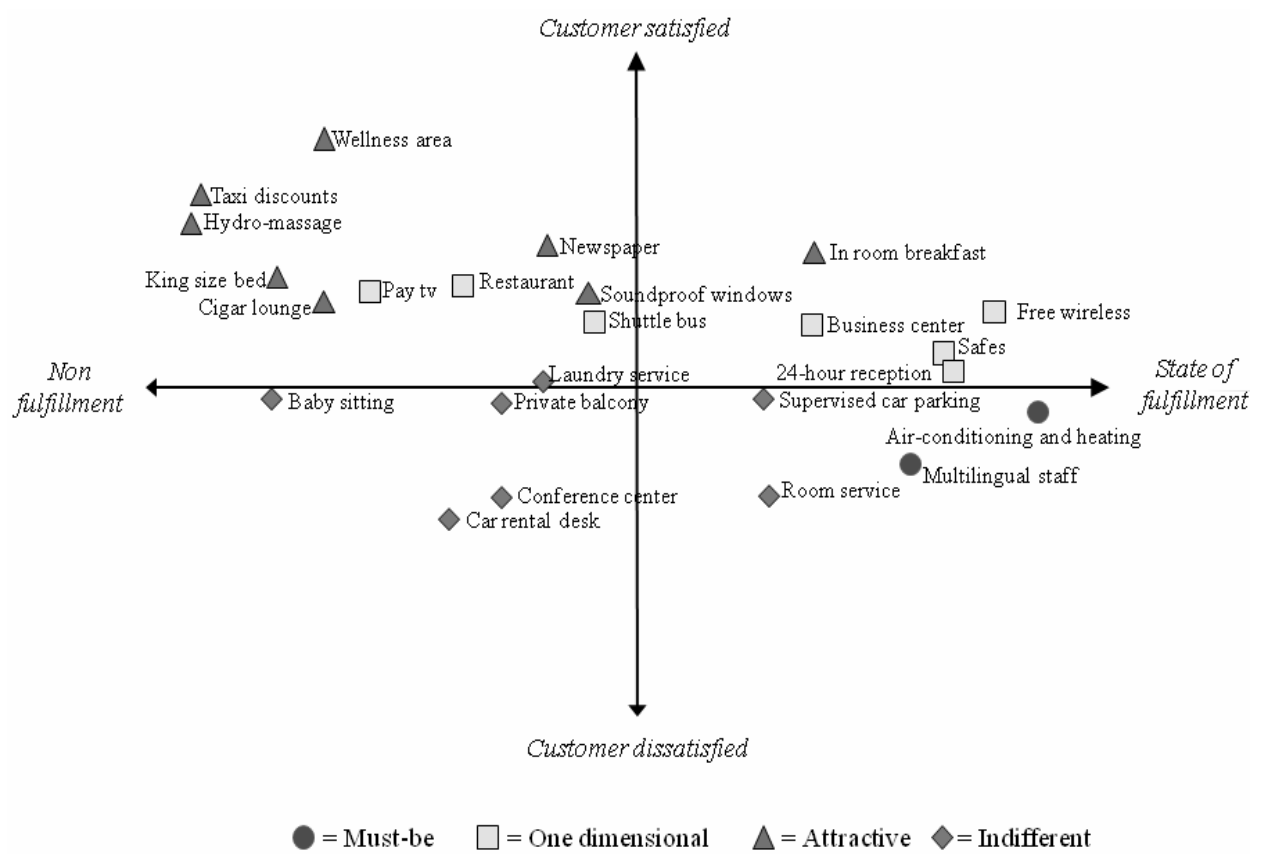

The Kano diagram, applied to the 20 hotels of our sample, suggests that customer preferences are not fully exploited and that the customer satisfaction level with the aggregated offers could increase if the following actions were undertaken:

- All the hotels in the sample should ensure the presence of air-conditioning and heating (1 missing) and of multilingual staff (4 missing).

- There are one-dimensional requirements which should be included in the offer of all the hotels: pay TV, a restaurant, shuttle buses, and business centres.

- The hotels in the sample could differentiate their offer by including one or more attractive requirements which have not yet been implemented - such as hydromassage bathtubs and taxi discounts - or which have only been implemented so far by a small number of hotels — such as wellness areas, king-size beds, and cigar lounges.

- Hotels should not invest further resources in indifferent services, such as supervised car parking, room service, laundry services, private balconies, conference centres, car-rental desks, or babysitting services. 


\section{Limitations of the study and further research}

Even though the cluster that we analysed was chosen for the representativeness of its hotels in the area, and even though the number of respondents is sufficient, the main limitation of this research (as with any other similar empirical study) is that it is circumscribed to one region, to a number of respondents, and to a fixed period of time. Of course, we do not assert that the results are representative of the reality everywhere worldwide. As in every model, the result has a "here and now" character, and the degree of potential for extending the forecast to "out there and in the future" depends on the similarity of the phenomenon examined.

We plan to develop further research in other regions and countries, in order to identify the impact of infrastructural differences on hotel service supply and guest satisfaction. One of the main constraints on the development of tourism in Sicily is the lack of quality transportation infrastructure (trains, bus services, and so on). An analysis of the impact of infrastructural deficiencies through a comparative study with other, more developed regions in Mediterranean Europe would also be useful in designing better regional development plans for the tourist industry in Sicily.

\section{Acknowledgements}

To conform with Italian regulations on academic publishing, even though the article is the joint work of both authors, we attribute the contribution of each author as follows: sections 1, 2, 3 and 6 can be credited to Gandolfo Dominici and sections 4 and 5 to Federica Palumbo.

\section{References}

Akbar, S., Som, A.P.M., Wadood, F. and Alzaidiyeen, N.J. (2010) 'Revitalization of service quality to gain customer satisfaction and loyalty', International Journal of Business and Management, Vol. 5, No. 6, pp.113-122.

Ananth, M., DeMicco, F.J., Moreo, P.J. and Howey, R.M. (1992) 'Marketplace lodging needs of mature travelers', The Cornell Hotel and Restaurant Administration Quarterly, Vol. 33, No. 4, pp.12-24.

Atkinson, A. (1988) 'Answering the eternal question: what does the customer want?', The Cornell Hotel and Restaurant Administration Quarterly, Vol. 29, No. 2, pp.12-14.

Barsky, J. and Labagh, R. (1992) 'A strategy for customer satisfaction', The Cornell Hotel and Restaurant Administration Quarterly, Vol. 35, No. 3, pp.32-40.

Barsky, J. and Nash, L. (2006) 'Companies update loyalty programs, increase effectiveness', Hotel \& Motel Management, Vol. 22, No. 11, pp.28-29.

Berger, C., Blauth, R., Boger, D., Bolster, C., Burchill, G., DuMouchel, W., Pouliot, F., Richter, R., Rubinoff, A., Shen, D., Timko, M. and Walden, D. (1993) 'Kano's method for understanding customer-defined quality', Center for Quality of Management Journal, Vol. 2, No. 4, pp.3-35.

Berkman, H.W. and Gilson, C. (1986) Consumer Behavior: Concepts and Strategies, 3rd ed., Kent, Boston. 
Cadotte, E.R. and Turgeon, N. (1988) 'Key factors in guest satisfaction', The Cornell Hotel and Restaurant Administration Quarterly, Vol. 28, No. 4, pp.45-51.

Chand, M. (2010) 'The impact of HRM practices on service quality, customer satisfaction and performance in the Indian hotel industry', The International Journal of Human Resource Management, Vol. 21, No. 4, pp.551-566.

Changa, K.C. and Chen, M.C. (2011) 'Applying the Kano model and QFD to explore customers' brand contact in the hotel business: a study of a hot spring hotel', Total Quality Management, Vol. 22, No. 1, pp.1-27.

Chaudha, A., Jain, R., Singh, A.R. and Mishra, P.K. (2011) 'Integration of Kano's model into quality function deployment', International Journal of Advanced Manufacturing Technology, Vol. 53, Nos. 5-8, pp.689-698.

Choi, T.Y. and Chu, R. (2001) 'Determinants of hotel guests' satisfaction and repeat patronage in Hong Kong hotel industry', International Journal of Hospitality Management, Vol. 20, No. 3 , pp.277-297.

Dominici, G. and Palumbo, F. (2012) 'How to build an e-learning product: factors for student/customer satisfaction', Business Horizons, Vol. 56, No. 1, pp.87-96.

Dominici, G. and Guzzo, R. (2010) 'Customer satisfaction in the hotel industry: a case study from Sicily', International Journal of Marketing Studies, Vol. 2, No. 2, pp.3-12.

Dominici, G. (2009) E-Marketing. Analisi dei cambiamenti dai modelli di business al mix operative, FrancoAngeli, Milan.

Fornell, C. (1992) 'A national customer satisfaction barometer: the Swedish experience', Journal of Marketing, Vol. 56, No. 1, pp.6-21.

Fyall, A., Callod, C. and Edwards, B. (2003) 'Relationship marketing: the challenge for destinations', Annals of Tourism, Vol. 30, No. 3, pp.644-659.

Gruen, T.W., Summers, J.O. and Acito, F. (2000) 'Relationship marketing activities, commitment, and membership behaviors in professional associations', Journal of Marketing, Vol. 64, No. 3 , pp.34-49.

Halstead, D. and Page, T.J. (1992) 'The effects of satisfaction and complaining behavior on consumers repurchase behavior', Journal of Satisfaction, Dissatisfaction and Complaining Behavior, Vol. 5, pp.1-11.

Hayes, B.E. (2008) Measuring Customer Satisfaction and Loyalty, 3rd ed., ASQ Quality Press, Milwaukee, USA.

Jones, D.L., Mak, B. and Sim, J. (2007) 'A new look at the antecedents and consequences of relationship quality in the hotel service environment', Services Marketing Quarterly, Vol. 28, No. 3, pp.15-31.

Kano, N., Seraku, N., Takahashi, F. and Tsuji, S. (1984) 'Attractive quality and must-be quality', Hinshitsu: The Journal of the Japanese Society for Quality Control, Vol. 14, No. 2, pp.39-48.

Kim, W.G., Han, J.S. and Lee, E. (2001) 'Effects of relationship marketing on repeat purchase and word of mouth', Journal of Hospitality \& Tourism Research, Vol. 25, No. 3, pp.272-288.

Knutson, B. (1988) 'Frequent travelers: making them happy and bringing them back', The Cornell Hotel and Restaurant Administration Quarterly, Vol. 29, No. 1, pp.83-87.

Lam, T. and Zhang, H. (1999) 'Service quality of travel agents: the case of travel agents in Hong Kong', Tourism Management, Vol. 20, No. 3, pp.341-349.

LeBlanc, G. and Nguyen, N. (1996) 'An examination of the factors that signal hotel image to travelers', Journal of Vacation Marketing, Vol. 3, No. 1, pp.32-42.

LeBlanc, G. (1992) 'Factors affecting customer evaluation of service quality travel agencies: an investigation of customer perceptions', Journal of Travel Research, Vol. 30, No. 4, pp.10-16.

Lee, J., Lee, J. and Feick, L. (2006) 'Incorporating word-of-mouth effects in estimating customer lifetime value', Journal of Database Marketing \& Customer Strategy Management, Vol. 14, No. 1, pp.29-39. 
Lee, Y.H. and Chen, T.L. (2006) 'A Kano two-dimensional quality model in Taiwan's hot spring hotels service quality evaluations', The Journal of American Academy of Business, Vol. 8, No. 2, pp.301-306.

Matzler, K. and Hinterhuber, H.H. (1998) 'How to make product development projects more successful by integrating Kano's model of customer satisfaction into quality function deployment', Technovation, Vol. 18, No. 1, pp.25-38.

McCleary, K.W., Weaver, P.A. and Hutchinson, J.C. (1993) 'Hotel selection factors as they relate to business travel situations', Journal of Travel Research, Vol. 32, No. 2, pp.42-48.

Mohajerani, P. and Miremadi, A. (2012) 'Customer satisfaction modeling in hotel industry: a case study of Kish Island in Iran', International Journal of Marketing Studies, Vol. 4, No. 3, pp.134-152.

Oh, H. and Parks, S.C. (1997) 'Customer satisfaction and service quality: a critical review of the literature and research implications for the hospitality industry', Hospitality Research Journal, Vol. 20, No. 3, pp.35-64.

Oppermann, M. (1998) 'Destination threshold potential and the law of repeat visitation', Journal of Travel Research, Vol. 37, No. 2, pp.131-137.

Parasuraman, A., Zeithaml, V.A. and Berry, L.L. (1988) 'SERVQUAL: a multiple-item scale for measuring consumer perceptions of service quality', Journal of Retailing, Vol. 64, No. 1, pp. $12-40$.

Pizam, A. (1994) 'Monitoring customer satisfaction', in Davis, B. and Lockwood, A. (Eds): Food and Beverage Management: A Selection of Readings, Butterworth-Heinemann, London.

Richard, M.D. and Sundaram, D.S. (1993) 'Lodging choice intentions: a causal modeling approach', Journal of Hospitality and Leisure Marketing, Vol. 1, No. 4, pp.81-98.

Rivers, M.J., Toh, R.S. and Alaoui, M. (1991) 'Frequent-stayer programs: the demographic, behavioral, and attitudinal characteristics of hotel steady sleepers', Journal of Travel Research, Vol. 30, No. 2, pp.41-45.

Saeed, I., Niazi, M.A., Arif, M. and Jehan, N. (2011) 'Antecedents of customer satisfaction and its outcomes. A study of Pakistani service sector', Interdisciplinary Journal of Contemporary Research in Business, Vol. 3, No. 8, pp.877-889.

Shiba, S., Graham, A. and Walden, D. (1993) A New American TQM, Four Practical Revolutions in Management, Productivity Press, Portland.

Sim, J., Mak, B. and Jones, D. (2006) 'A model of customer satisfaction and retention for hotels', Journal of Quality Assurance in Hospitality \& Tourism, Vol. 7, No. 3, pp.1-23.

Spinelli, M.A. and Canavos, G.C. (2000) 'Investigating the relationship between employee satisfaction and guest satisfaction', Cornell Hotel and Restaurant Administration Quarterly, Vol. 41, No. 6, pp.29-33.

Stevens, P., Knutson, B. and Patton, M. (1995) 'DINESERV: a tool for measuring service quality in restaurants', Cornell Hotel and Restaurant Administration Quarterly, Vol. 36, No. 2, pp.56-60.

Tarn, D. (2005) 'Marketing-based tangibilisation for services', Service Industries Journal, Vol. 25, No. 6, pp.747-772.

Trusov, M., Bucklin, R. and Pauwells, K. (2009) 'Effects of word-of-mouth versus traditional marketing: findings from an internet social networking site', Journal of Marketing, Vol. 73, No. 5, pp.90-102.

Vijayadurai, J. (2008) 'Service quality, customer satisfaction and behavioural intention in hotel industry', Journal of Marketing \& Communication, Vol. 3, No. 3, pp.14-26.

Villanueva, J., Yoo, S. and Hanssens, D. (2008) 'The impact of marketing-induced versus word-ofmouth customer acquisition on customer equity growth', Journal of Marketing Research, Vol. 45, No. 1, pp.48-59. 
Wilensky, L. and Buttle, F. (1988) 'A multivariate analysis of hotel benefit bundles and choice trade-offs', International Journal of Hospitality Management, Vol. 7, No. 1, pp.29-41.

Wuest, B.E.S., Tas, R.F. and Emenheiser, D.A. (1996) 'What do mature travelers perceive as important hotel/motel customer service?', Hospitality Research Journal, Vol. 20, No. 2, pp.77-93.

Yang, C.C., Cheng, L.Y., Sung, D. and Withiam, G. (2009) 'Strategic-pricing policy based on analysis of service attributes', Cornell Hospitality Quarterly, Vol. 50, No. 4, pp.498-509.

Yen, A. and $\mathrm{Su}, \mathrm{L}$. (2004) 'Customer satisfaction measurement practice in Taiwan hotels', Hospitality Management, Vol. 23, No. 4, pp.397-408.

\section{Note}

1 Questionable requirements $(\mathrm{Q})$ are those for which it is unclear how customers consider them. This can happen because of ambivalent responses due to a misunderstanding of the question, or erroneously filling-out the questionnaire. 